University of Nebraska - Lincoln

DigitalCommons@University of Nebraska - Lincoln

1995

\title{
Seasonal Land-Cover Regions of the United States
}

Thomas R. Loveland

U.S. Geological Survey Earth Resources Observation and Science (EROS) Center, Sioux Falls, SD

James W. Merchant

Institute of Agriculture and Natural Resources, University of Nebraska

Jesslyn F. Brown

Hughes STX Corporation, EROS Data Center

Donald O. Ohlen

Hughes STX Corporation, EROS Data Center

Bradley C. Reed

Hughes STX Corporation, EROS Data Center, reed@usgs.gov

See next page for additional authors

Follow this and additional works at: https://digitalcommons.unl.edu/natrespapers

Part of the Natural Resources and Conservation Commons, Natural Resources Management and Policy Commons, and the Other Environmental Sciences Commons

Loveland, Thomas R.; Merchant, James W.; Brown, Jesslyn F.; Ohlen, Donald O.; Reed, Bradley C.; Olson, Paul; and Hutchinson, John, "Seasonal Land-Cover Regions of the United States" (1995). Papers in Natural Resources. 475.

https://digitalcommons.unl.edu/natrespapers/475

This Article is brought to you for free and open access by the Natural Resources, School of at DigitalCommons@University of Nebraska - Lincoln. It has been accepted for inclusion in Papers in Natural Resources by an authorized administrator of DigitalCommons@University of Nebraska - Lincoln. 


\section{Authors}

Thomas R. Loveland, James W. Merchant, Jesslyn F. Brown, Donald O. Ohlen, Bradley C. Reed, Paul Olson, and John Hutchinson

This article is available at DigitalCommons@University of Nebraska - Lincoln: https://digitalcommons.unl.edu/ 


\title{
Map Supplement
}

\section{Seasonal Land-Cover Regions of the United States}

\author{
Thomas R. Loveland,* James W. Merchant, ** Jesslyn F. Brown, ${ }^{* * *}$ Donald O. Ohlen, ${ }^{* * *}$ \\ Bradley C. Reed, ${ }^{* * *}$ Paul Olson, ${ }^{* * *}$ and John Hutchinson*** \\ *U.S. Geological Survey, EROS Data Center \\ **Institute of Agriculture and Natural Resources, University of Nebraska \\ ***Hughes STX Corporation, EROS Data Center
}

Regionalization, an important and classic method of geographical research, requires new refinements and innovative applications for use in analyzing global change. (Mather and Sdasyuk 1991:152)

$\mathbf{R}$ esearch on global change has been hindered by deficiencies in the availability and quality of land-cover data (Mather and Sdasyuk 1991; Townshend 1992). To address this deficiency, the U.S. Geological Survey (USGS) and the University of NebraskaLincoln have collaborated in developing a method of land-cover characterization that is suitable for research on global change and on regional patterns of land cover (Loveland et al. 1991; Brown et al. 1993). This methodology is based upon statistical analysis of multidate, meteorological satellite imagery acquired by the National Oceanic and Atmospheric Administration's (NOAA) Advanced Very High Resolution Radiometer (AVHRR) sensor complemented by ancillary spatial data. The product of this analysis-a multi-level, digital, geographically referenced land-cover database (hereafter referred to as the database) covering the coterminous United States-serves as a prototype for a global land-cover database which is currently under development.

The study of global change requires improved regional frameworks (for example, Turner, Moss, and Skole 1993; Mather and Sdasyuk 1991). The land-cover characterization strategy developed in this study is based upon regionalization of the seasonal expression of vegetative development. This ap- proach is well-suited for global-change research because of the explicit manner in which critical biophysical conditions are used to define and characterize land-cover regions. Moreover, the regionalization process presented here has the advantages of replicability, computational manageability, flexibility, and global applicability.

The USGS-Nebraska study was undertaken in order to generate digital maps for climatic, hydrologic, and ecologic modeling and other applications in which land-cover data are required (Steyaert et al. 1994). This paper draws upon that digital database in constructing maps of selected land-cover characteristics of the continental United States. These maps are illustrative of the variety of maps that can be produced from the digital database. The paper describes the methods used to prepare the database, presents an experimental map supplement portraying seasonal land-cover regions of the U.S. based on the analysis of multitemporal AVHRR and ancillary spatial data, and provides guidance for prospective users of the digital database.

The maps in this paper represent a few of the cartographic products that might be derived from the database. Many others are possible, however, because our approach affords users the opportunity for customizing products to specific needs. Because no single map or set of maps can convey fully the richness of the database, visualization tools such as those commonly found in geographic information systems (GIS) as well as new specialized car- 
tographic software provide appropriate means for exploiting the database (for example, Egbert and Slocum 1992).

\section{Global Land-Cover Requirements for Biophysical Modeling}

Because of the wide variety of scales, classification schemes, and derived land-cover parameters that are employed by students of global change, current global land-cover databases (UNESCO 1973; Olson and Watts 1982; Matthews 1983) are unable to fill many emerging research needs. Consequently, the selection of a land-cover framework usually depends more on data availability than on the suitability of that framework for the problem at hand. Equally problematic is the wide range and variety of global-change applications which require land-cover data. These include such different applications as atmospheric mesoscale and general circulation modeling, water-resources assessment, and ecological modeling (for more extensive reviews, see Baker 1989; Henderson-Sellers and McGuffie 1987; Sklar and Costanza 1990; and Goodchild et al. 1993). Accordingly, land-cover typologies and their spatial resolutions will vary both within and between applications. Table 1 summarizes the land-cover inputs (classification schemes, attributes, and spatial scale) required by ten selected models.

In the case of atmospheric models, climatologists and meteorologists construct mesoscale and general circulation models (GCMs) to estimate a range of future weather or climate conditions. Mesoscale models operate in a regional context with typical spatial resolutions of 1 to 40 kilometers; GCM's are global in scale and require resolutions on the order of $2 \times 4$ degrees latitude/longitude or greater. Models at both scales use land-surface parameterization schemes to determine land/atmosphere interactions. For example, the Biosphere Atmosphere Transfer Scheme (BATS) (Dickinson et al. 1986) and the Simple Biosphere Model (SiB) (Sellers et al. 1986; Xue et al. 1991) link data on land cover with measures of fractional land cover, roughness, albedo, and other land characteristics for calculating water and energy-exchange fluxes for grid cells. Note, however, that the land-cover types used in BATS and SiB differ in the number of classes (there are 18 BATS versus $13 \mathrm{SiB}$ classes in the U.S.), the definitions of classes, and the variety of attributes that describe land-cover properties.

Similarly, hydrological models typically require information on land cover, soils, and terrain for the purpose of defining homogeneous hydrologic-response units (HRUs) for their computations. HRUs typically are defined by relatively simple land-cover classes, e.g., bare soil, grasses, bushes/shrubs, and trees, and for multiple grids, e.g., 2.5-, 5-, and $10-\mathrm{km}$ grid cells or variously sized polygons associated with watershed basin characteristics.

Ecosystem models meanwhile use landcover data for estimating a range of measures of ecosystem functions and dynamics, e.g., primary productivity, biogeochemical cycling, and biogenic emissions. The ecosystem model CENTURY simulates the temporal dynamics of soil organic matter and plant production in grazed grasslands (Parton et al. 1987; Burke et al. 1991) using land-cover (particularly landuse) and monthly climate data as key inputs. The specific land-cover classes used in the CENTURY model vary, however, according to the application. The Regional Hydrological Ecosystem Simulation System (RHESSys) model requires, by contrast, broad land-cover data at the biome scale, i.e., grasses, shrubs, coniferous, and deciduous forests, at 1 - to $60-\mathrm{km}$ grid cell sizes. This model uses land-cover attributes for each cover class in combination with satellite-derived estimates of leaf area and daily weather data in order to calculate water, energy, and trace-gas fluxes (Running 1990).

\section{Optimal Global Land-Cover Data for Global-Change Research}

Existing land-cover maps of the continents and the globe are uniformly small in scale, coarse in spatial resolution, variable in quality and reliability, and ill-suited for alternative modeling applications (Townshend 1992; Henderson-Sellers and Pitman 1992; Townshend et al. 1991). Accordingly, the design of an optimal land-cover data set for global-change research should overcome these deficiencies. It should: 1) derive from a single set of relatively high- 
Table 1. Land-Cover Characteristics Input Requirements and Spatial Scale for Selected Modeling Applications and Models.

\begin{tabular}{|c|c|c|c|c|}
\hline & Model & $\begin{array}{l}\text { Classification } \\
\text { Scheme }\end{array}$ & Spatial Scale & $\begin{array}{l}\text { Associated } \\
\text { Attributes }\end{array}$ \\
\hline \multirow[t]{3}{*}{$\begin{array}{l}\text { General Circulation } \\
\text { Models }\end{array}$} & NASA/GSFC & $\mathrm{SiB}$ & $4 \times 5$ degrees & $\begin{array}{l}\text { SiB set and NDVI } \\
\text { derivatives }\end{array}$ \\
\hline & $\begin{array}{l}\text { University of } \\
\text { Maryland-COLA }\end{array}$ & Simplified SiB & $\begin{array}{l}4.5 \times 7.8 \text { degrees } \\
1.8 \times 2.8 \text { degrees }\end{array}$ & $\begin{array}{l}\text { SSiB set and NDVI } \\
\text { derivatives }\end{array}$ \\
\hline & NCAR-CCM & BATS & $2 \times 4$ degrees & $\begin{array}{l}\text { BATS set and } \\
\text { NDVI derivatives }\end{array}$ \\
\hline \multirow{2}{*}{$\begin{array}{l}\text { Mesoscale } \\
\text { Meteorological } \\
\text { Models }\end{array}$} & CSU-RAMS & LEAF & $\begin{array}{c}\text { Nested Grids of } \\
1,10,40 \mathrm{~km}\end{array}$ & $\begin{array}{l}\text { LEAF Set and } \\
\text { NDVI derivatives }\end{array}$ \\
\hline & PSU-NCAR MM4 & BATS & $\begin{array}{c}\text { Nested Grids of } \\
4,12,36 \mathrm{~km}\end{array}$ & $\begin{array}{l}\text { BATS Set and } \\
\text { NDVI derivatives }\end{array}$ \\
\hline \multirow[t]{2}{*}{ Hydrologic Models } & $\begin{array}{l}\text { Watershed } \\
\text { Precipitation/Runoff }\end{array}$ & Basic Classes & $2.5,5,10 \mathrm{~km}$ & model specific \\
\hline & $\begin{array}{l}\text { Agricultural } \\
\text { Chemical Runoff }\end{array}$ & $\begin{array}{l}\text { Anderson } \\
\text { Level II }\end{array}$ & $\begin{array}{l}\text { country level or } \\
1 \mathrm{~km}\end{array}$ & model specific \\
\hline \multirow[t]{3}{*}{ Ecosystem Models } & RHESSys & Basic Biomes & $1-50 \mathrm{~km}$ & $\begin{array}{l}\text { RHESSys Set and } \\
\text { NDVI derivatives }\end{array}$ \\
\hline & CENTURY & $\begin{array}{c}\text { Anderson } \\
\text { Level II }\end{array}$ & $1-50 \mathrm{~km}$ & NDVI derivatives \\
\hline & Biogenic Emissions & $\begin{array}{l}\text { Key species } \\
\text { (oak, hickory, } \\
\text { etc.) }\end{array}$ & $20 \mathrm{~km}$ & NDVI derivatives \\
\hline
\end{tabular}

Table of Abbreviations

BATS

Biosphere-Atmosphere-Transfer-Scheme

COLA Center for Ocean-Land-Atmosphere

CSU-RAMS Colorado State University-Regional Atmospheric Modeling System

GSFC Goddard Space Flight Center

LEAF Land-Ecosystem-Atmosphere-Feedback

NCAR-CCM National Center for Atmospheric Research, Climate Community Model

NDVI Normalized Difference Vegetation Index

PSU/NCAR-MM4 Penn State University/National Center for Atmospheric Research-Mesoscale Meteorology

RHESSys Regional Hydrological Ecosystem Simulation System

SiB Simple Biosphere model

SSiB $\quad$ Simplified Simple Biosphere model

resolution source data acquired within a narrow window of time (e.g., 1 or 2 years); 2) employ a flexible land-cover classification that permits users to tailor their products for specific applications; 3 ) rely upon systematic analytical procedures; 4) capture important seasonal and interannual trends; 5) facilitate biophysical interpretation; and 6) ensure replicability for the purpose of long-term monitoring (Townshend 1992).

Conventional land-cover maps do not achieve these objectives since their developers have designed them to serve the singular purposes of specific user-groups. Digital spatial databases, by contrast, enable all users to extract the data and create customized maps and other products that meet specialized user re- quirements (Goodchild 1988). The virtues of such a flexible database are increasingly obvious since they permit multiple applications as well as the opportunity to interactively "explore the database underlying a map" (Egbert and Slocum 1992).

\section{Land-Cover Regionalization}

Regionalization, long a hallmark of geographic research (Grigg 1965; 1967; Spence and Taylor 1970; Gardiner and Gregory 1977; Haggett et al. 1977; Hart 1982; Turner, Moss, and Skole 1993), is garnering increasing attention among students of global change (Mather and Sdasyuk 1991; Peplies and Honea 1992). 
The latter have realized that regions can serve as units of analysis that capture important aspects of landscape variability over large areas. In addition, regions offer an efficient and flexible spatial framework for summarizing the often complex ecosystem parameters that are required in environmental modeling (Omernik and Gallant 1990).

The rich and extensive literature on regionalization is, of course, well-known to geographers (for example, Grigg 1967; Haggett et al. 1977; Hart 1982). For purposes of this paper, we employ a method of land-cover regionalization which defines uniform regions based upon seasonal characteristics of land cover augmented by other descriptive attributes. Regionalization, in this regard, represents a special form of classification (Grigg 1967). Classifications of landscape regions may be based on one variable (monothetic) or many (polythetic) (Spence and Taylor 1970; Gardiner and Gregory 1977). Examples of monothetic or univariate regionalization include Küchler's map of the potential vegetation of the United States and Anderson's depiction of land-use and land-cover regions for that same nation (Küchler 1964; U.S. Geological Survey 1970). Polythetic or multivariate regionalization (Spence and Taylor 1970) is illustrated by the maps of ecoregions (produced by Omernik 1987; and Bailey 1980; 1983) which are defined as multivariate associations of climate, geology, terrain, soils, and vegetation.

Our classification of land-cover characteristics for the United States is most closely related to the polythetic regionalization model. This decision signals a departure from the norm of land-cover regionalizations derived from remote sensing which employ a monothetic approach. In these cases, image analysts assign each pixel to one, and only one, category in a land-cover classification system (such as, for example, Anderson et al. 1976; or Jennings 1993). While the monothetic approach may produce land-cover maps that are wellsuited for certain types of land-management activities (e.g., wildlife-habitat evaluation or soil-erosion hazard assessment), the method lacks the flexibility that is required for many environmental models (Omernik and Gallant 1990). The fact that monothetic mapping is often designed for a specific need for landcover data means that this procedure is usually ill-suited for other applications (Peplies and
Honea 1992). For optimal flexibility of usage, a land-cover database should accommodate a broad range of temporal, spatial, and categorical aggregations that are suited to variable applications requirements (Peer 1990; Reed et al. 1994b). Achieving such flexibility is the main purpose for which the U.S. land-cover database has been designed.

\section{Sources of Land-Cover Data: Satellite Remote Sensing}

Earth-observing satellites (e.g., Landsat, SPOT) have been collecting data for more than 20 years. These data are routinely used for land-cover assessment, although several practical issues have limited their usefulness for land-cover mapping over subcontinental or larger areas (Goward 1990). The large volume of data (number of scenes and number of pixels) required to cover even a single continent and the complexity of data acquisition and analysis have made such analyses prohibitively expensive (see Woodwell et al. 1984). Moreover, the revisit period (e.g., 16 days for Landsat) of the current earth-observing satellites is such that, in most instances, the generation of a cloud-free high-quality set of images entails assembling scenes acquired over several years and many seasons.

Because of such difficulties in using earth-observing satellites for large-area land-cover assessments, attention in recent years has shifted to the potential application of meteorological satellite data for such ventures. Most efforts have focused on the Advanced Very High Resolution Radiometer (AVHRR), a sensor carried on the National Oceanic and Atmospheric Administration's (NOAA) series of polar-orbiting meteorological satellites. The AVHRR provides low-cost daily global coverage at 1.1 by 1.1 kilometer spatial resolution (note that we resampled the $1.1-\mathrm{km}^{2}$ AVHRR data to a nominal $1-\mathrm{km}$ resolution for this study; hence, subsequent references are to the $1-\mathrm{km}$ data). The high frequency of observation affords many opportunities for acquisition of cloud-free data over relatively short periods of time (e.g., a growing season) and facilitates the compilation of information on seasonal changes in land-surface characteristics. Moreover, the 1-km spatial resolution produces a manageable volume of 
data even for the global scale (Townshend 1992).

Although designed mainly for atmospheric rather than earth observation, the AVHRR sensor is also useful for land-cover assessment. In most instances, data from AVHRR channels 1 (reflected red light -0.58 to 0.68 micrometers) and 2 (reflected near infrared-0.725 to 1.10 micrometers) are used to compute an index of vegetation "greenness" (the normalized difference vegetation index or NDVI) for each $1-\mathrm{km}$ pixel (Eidenshink 1992). This index of "greenness" is broadly correlated in turn with several biophysical parameters such as levels of photosynthetic activity, primary production, leaf area, and $\mathrm{CO}_{2}$ flux (see Box et al. 1989; Goward and Huemmirch 1992; Ludeke et al. 1991; Spanner et al. 1990; and Tucker et al. 1983).

Cloud-free greenness maps of the earth's surface are assembled from multidate composite images. The USGS EROS Data Center, for example, produces a 14-day composite greenness image for the coterminous U.S. (available on CD-ROM; Eidenshink 1992). The EROS composite images are constructed by assigning each pixel the highest NDVI recorded in that pixel during the 14-day period. This process tends to eliminate clouds except in areas where there are no cloud-free pixels during the 14-day period. A time series of these composite "greenness" images depicts phenological events, most notably the annual progression from Spring greenup ("green wave") when the northern hemisphere's deciduous trees develop leaves and crops emerge and develop to the ensuing Fall's retrogression ("brown wave") when trees drop their leaves and crops reach senescence and are harvested (Goward et al. 1985; Goward 1989). With data such as these we are able to define regions having distinctive seasonal characteristics.

The graph in Figure 1 provides an example of a greenness (NDVI) profile for lowa. The graph describes the characteristic increase in greenness ("onset") starting in May as the row crops (e.g., corn and soybeans) emerge and develop, the peaking of greenness in early August as crops reach their maximum development, and the decrease of greenness in early Fall associated with senescence and harvest. lowa's profile of greenness advance, peak, and retreat is quite different, however, from other areas with different cover types. The U.S. data-

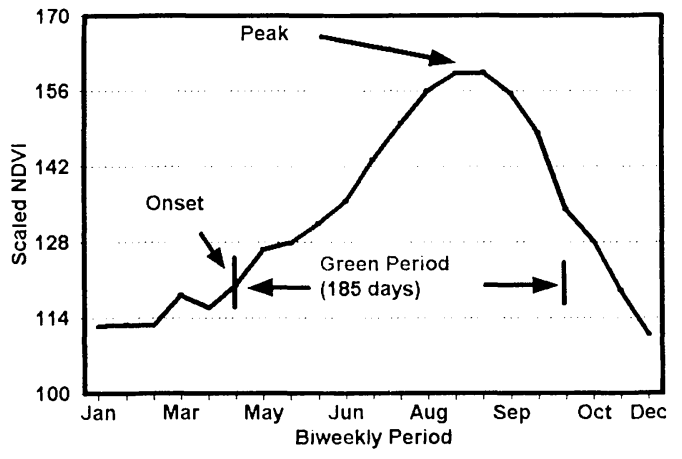

Figure 1. Sample temporal profile for the central Corn Belt showing the relationships between NDVI and the timing of the onset and peak of greenness and the duration of the green period in 1990.

base project takes advantage of this variability in sequencing which enables land cover in a given region to be characterized by the annual multitemporal trajectory of greenness associated with that region.

The utilization of AVHRR data for large-area, land-cover assessment extends back nearly 15 years (Townshend et al. 1991). Most of this research uses AVHRR data resampled to $4-\mathrm{km}^{2}$ or $16-\mathrm{km}^{2}$ pixels. For example, AVHRR data at a resolution of $4-\mathrm{km}^{2}$ has been used for defining major biomes and observing phenological change over the African continent for a 19month period in 1982 and 1983 (Tucker, Townshend, and Goff 1985), and for classifying land cover in South America (Townshend, Justice, and Kalb 1987). Moreover, seasonal NDVI patterns have been used to test associations with major land-cover regions of North America and to document major phenological events (Goward, Tucker, and Dye 1985). World biomes have been mapped using a supervised binary decision tree classification of multidate AVHRR data (Lloyd 1991), and global phytoclimatological conditions have been examined using biweekly AVHRR data (Gallo and Brown 1990).

The use of finer-resolution AVHRR data for land-cover assessment is less common because the data generally are not available over large areas of the globe (Ehrlich, Estes, and Singh 1994). Studies that have employed $1-\mathrm{km}$ AVHRR data have usually focused on small ar- 
eas (see Tucker, Gatlin and Schneider 1984; Gervin et al. 1985). Recently, however, several studies have used 1-km AVHRR data for large area land-cover studies. Using 1-km AVHRR data, Zhu and Evans (1994) mapped forest types and forest density for the coterminous United States, and Stone et al. (1994) constructed a general land-cover map of South America (largely from 1-km AVHRR data). One-kilometer AVHRR data also have been used for mapping general land-cover patterns of Canada as part of a national atlas project (Palko 1990). Promising as well is a collaborative effort aimed at providing data needed for a range of global-change research initiatives. In this case, a consortium of the USGS, National Aeronautics and Space Administration (NASA), NOAA, the European Space Agency, and the International Geosphere Biosphere Programme is developing a global time series of 1-km AVHRR data for the period April 1992 to September 1994.

\section{Producing the U.S. Land-Cover Database}

The production of the U.S. 1-km land-cover database began with assemblage of a national coregistered $1-\mathrm{km}$ dataset consisting of a set of eight monthly maximum NDVI composite images covering the period March-October 1990 along with data on elevation, climate, ecoregions, and related attributes (Loveland et al. 1991; Brown et al. 1993). The eight NDVI images were statistically clustered using the Isoclass clustering algorithm, a per-pixel algorithm which has no contiguity constraints. The algorithm yielded 70 spectral-temporal ("seasonally-distinct") classes (regions). These regions were then collated with Landsat imagery, existing vegetation map observations, and other reference materials in order to develop a preliminary description of land cover in each of the 70 regions. These land-cover descriptions were then refined using a postclassification sorting procedure (Brown et al. 1993). Classes with similar seasonal NDVI profiles, but different vegetative components, were subdivided into internally homogeneous land-cover regions. This resulted in a database containing 159 seasonal land-cover regions and their corresponding descriptions.
The 159 land-cover regions were then crosstabulated with elevation, climate, ecoregions, land use, land cover, and ancillary data sets. This cross tabulation enables database users to determine the topographic and climatic characteristics of a given land-cover region. Tables linking the AVHRR-derived database and other commonly used land-cover classification systems (e.g., Anderson's USGS scheme, BATS, and $\mathrm{SiB}$ ) were created to facilitate translations between the systems. Finally, parameters such as the timing of vegetative onset and peak greenness and the duration of the green period were derived from AVHRR data for JanuaryDecember 1990. The entire U.S. database-including source data, classification, derived and ancillary data, tabular data, and documentation-is available on CD-ROM (USGS EROS Data Center, Sioux Falls, SD 57198) (Table 2). ${ }^{1}$

\section{Preparing the Map Supplement}

We then turned to the cartographic representation of these data. An experimental map portraying the land-cover regions and selected seasonal characteristics was produced. This $1: 7,500,000$-scale map depicted the 159 seasonal land-cover regions grouped into major cover types. The legend listed typical vegetation or land-cover types found in each region. In some cases, two or more classes were indicated as having the same land-cover types. In these cases, the several regions share common land-cover attributes, but differ in the seasonal characteristics of vegetative development or in the relative levels of vegetative productivity.

The presentation of the 159 seasonal landcover regions at this small a scale constituted a major challenge. Because of the fine spatial resolution of the database and because some of the regions are very small, techniques such as pattern overlays or region labeling (as used on Küchler's map of potential natural vegetation) were not feasible. We developed instead a technique that designated a distinct hue for each group of cover types. The selection of hues was based on standard cartographic conventions for color representation of vegetation types, i.e., green for forests and yellow for grasslands. Within each cover-type group, darker hues represent increasing relative levels of annual primary production (estimated from annual total NDVI). For example, we divided 
Table 2. U.S. Land-Cover Characteristics Database.

Land-cover Classifications

Preliminary Classification (70 Classes)
Final Classification (159 Classes)

Source Raster Files

1990 March-October 28-day NDVI composites (Eidenshink 1992)

1990 maximum NDVI

USDA Major Land Resource Areas (USDA 1981)

EPA ecoregions (Omernik 1987)

Digital elevation

Water bodies (lakes, reservoirs, and large rivers)

USGS Land Use and Land Cover (USGS 1986)

Frost-free period (NOAA 1979)

Political boundaries

Derived Raster Files

USGS Land Use and Land Cover

Simple Biosphere Model

Biosphere-Atmosphere Transfer Scheme

Onset of greenness

Peak of greenness

Duration of greenness

Descriptive and Statistical Attributes

Major vegetation and land-cover types

1990 NDVI statistics

1990 AVHRR channels $1-5$ statistics

Elevation statistics

USGS Land Use and Land Cover statistics

USDA Major Land Resource Areas statistics

EPA ecoregions statistics

Seasonal characteristics

Frost-free period statistics

Climate summary statistics

"savanna" in the grasslands group into four regions (classes 86-89) based on seasonal greenness patterns; these appear as a graduated series of yellow hues. The light yellow hue of Class 86 indicates relatively lower annual primary production than the darker yellow hue of Class 89.

In addition, we had to accommodate the large number of regions, some quite small in area, and the difficulty of differentiating among the 159 uniquely colored classes. Toward that end, color selection has taken into account regional contiguity in order to minimize the assignment of similar colors to adjacent regions. For example, although the shades of green used to symbolize southeast mixed forest and western woodlands are similar, these classes of land-cover are geographically separated and hence more easily identifiable as distinct classes. Conversely, small grains and row crops often occur in adjacent locations, and in order to maintain visual separation, these were assigned colors of orange and brown, respectively.

In addition to the 159-class land-cover map, the map supplement includes several other maps derived from the database. The USGS level II land-cover map on the reverse side of the Supplement portrays the 159 classes in the database aggregated into an approximation of the Anderson land-use and land-cover classification system-one of the most widely used systems in the U.S. (Anderson et al. 1976). The 26 land-cover classes derived reflect regional vegetation types and mosaics of land cover at $1-\mathrm{km}$ resolution. Translation tables for converting between our 159 seasonally based classes and Anderson's classification are part of the database. Our aggregation required some modification of the original Anderson classes because of differences in class characteristics and AVHRR data resolution. For example, instead of using the single level II deciduous forest category, we derived three deciduous forest classes (northern, southern, and western) which differ with respect to the dominant tree species found in each region. Mixed classes such as grassland/cropland and woodland/cropland were classified as complex regions with interspersed land-use/land-cover types.

The Map Supplement also contains a series of smaller-scale maps depicting 1990 seasonal characteristics of the 159 land-cover classes. One series of maps portrays the months in which the onset of greenness and peak greenness occurred and the other depicts the duration of the green period (an estimate of the length of growing season). Note that the Map Supplement presents monthly estimates of onset and peak seasonal characteristics (Figure 1), whereas our calculations of onset and peak are based on the nearest 1990 14-day period.

Onset of greenness is defined as the period in which significant development of standing green biomass was observed through the NDVI. Using a temporal NDVI profile graph, onset is typically defined as that point of steep upward inflection in the NDVI curve following 
the dormant season. Interpretation of this point is somewhat subjective, however, and the search for an objective quantitative means for detecting seasonal events from NDVI is underway (Reed et al. 1994a).

The maps portraying peak-greenness months are based upon the biweekly period which reported the highest level of greenness (NDVI) in 1990, i.e., the time period of maximum NDVI mean value for each of the 159 classes. Lastly, the map of the Length of Green Period shows the duration of greenness-defined as the number of days between onset and end of greenness (Figure 1). The end of the green period we defined as the biweekly period in which the NDVI dropped to a seasonal low corresponding to the NDVI level at the onset of greenness. The interval between the onset and the end of greenness thus equals the duration of the green period (expressed as number of days).

\section{Interpreting the U.S. Land-Cover Map}

The 159-region maps are based upon a remotely-sensed dataset collected over a single year. These maps have several advantages: 1 ) their resolution $(1 \mathrm{~km})$ is substantially finer than most comparable products; 2 ) the large number of regional classes exceeds those of similar maps (for example, U.S. Geological Survey 1970; Küchler 1964; Omernik 1987; Bailey 1980); and 3) the 159 regional classes incorporate seasonality and productivity as well as land cover. Whereas comparable maps present a single set of regions labeled "wheat," we discern several wheat regions with varying crop calendars (i.e., planting/harvesting dates) that correspond to higher latitude and/or elevation or climatic gradients. Moreover, because the land-cover data are registered to other databases (e.g., elevation, climate, ecoregions), users can explore relationships between the several datasets and construct products designed for their specialized needs.

Because the original AVHRR data have a resolution of approximately $1-\mathrm{km}$, mixtures of land-cover are commonly integrated within the AVHRR pixel. Even in areas largely devoted to crops, a $1-\mathrm{km}$ pixel will usually contain tracts of woodland, grass, and other cover types that exhibit phenologies different from crops. This is particularly evident in areas such as the Middle Atlantic states, where land cover is both diverse and highly fragmented into small parcels.

At first glance, the spatial complexity of the 159-class map may seem disconcerting, even noisy. While cartographers are still debating the merits, role, and procedures for data classification and presentation-generality versus detail-(Dent 1993; Egbert and Slocum 1992; Tobler 1973), our map aims to convey the overall pattern of land cover in a single year and to provide a realistic depiction of the spatial patterns of land cover. The $1-\mathrm{km}$ spatial resolution enables us to portray the fragmentation and patchiness of land cover which are not usually apparent in more generalized maps. In addition, by revealing the fuzzy nature of ecotones separating major landscape regions, the map underlines the role of ecotones as transition zones (Clarke et al. 1991).

The Map Supplement portrays many familiar patterns among the seasonal land-cover regions. Note, for example, the distinctive and relatively homogeneous land cover of the Corn Belt, the Ozark Uplands, the Palouse of Washington and the Flint Hills of Kansas. The map also captures the differences in the spatial structure of land cover across the nation. The highly fragmented depiction of the interior western landscapes of the basin and range province, for example, reflect the often dramatic variation in relief, elevation, and microclimate over relatively short distances in this region. The expression of underlying physical geography is evident elsewhere as well-on the eastern fall zone, the ridges and valleys of the southern Appalachian Mountains, along the Willamette valley of Oregon, amidst the Nebraska Sand Hills, and within the Black Hills of South Dakota.

Patterns on the derivative maps are, perhaps, less familiar because they have been infrequently (if ever) mapped at the spatial and temporal resolution of our database. Comparisons between the seasonal land-cover regions map and the derivative maps of onset, duration, and peak of greenness are informative and, at times, expose surprising relationships. For example, the late date of the onset of greenness in the croplands of the Mississippi floodplain (downstream from Cairo, Illinois) does not correspond with the seasonal char- 
acteristics of the surrounding region. Given a moderate climate, one might expect that crops there would be planted and mature to their peak greenness quite early by comparison to crops at more northerly latitudes. The maps show that this was not the case in 1990 . The maps thus lead us to explore this apparent anomaly. Anecdotal evidence suggests that high water tables and abundant precipitation in the spring may have resulted in saturated fields which delayed planting in this region; the matter clearly deserves more thorough research. Doubtless examination of the maps will reveal other anomalous areal relationships between land cover and regional seasonality. Some of these may reflect the specific meteorological conditions that existed in 1990, while others may suggest more durable anomalies that merit investigation.

Note that the 159-class map portrays seasonally distinct land cover and not land use (Campbell 1983). As a consequence, urbanized areas are represented by their constituent land-cover types (e.g., grassland, woodland, barren). Moreover, because class labeling has been optimized at the national level, urban mosaics of roads, buildings, and parks may appear as "desert shrubland" since their spectral and temporal characteristics often resemble that cover type. Persons interested in urban areas should be aware of the causes of this apparent mislabeling and may wish to assign more appropriate labels to areas of interest. Ancillary data sources can, of course, be used to identify urban areas as demonstrated in our USGS Level II Land-Cover map. In this case, urban areas were derived from the Digital Chart of the World and overlaid into the AVHRR-derived general land-cover map in order to provide map readers with a portrayal of the spatial extent of urban areas as well as an example of complementary use of data from different sources (Danko 1992).

\section{Understanding Seasonal Land-Cover Characterization}

To facilitate interpretation of the seasonality inherent in the land-cover database, we present a brief analysis of some representative land-cover classes. The temporal greenness profiles in Figures 2-5 depict the average NDVI for each of eight classes over the twenty-two 14-day intervals in 1990. Similar profiles for all other classes can be extracted from the database.

Figure 2 displays 1990 NDVI profiles for two agricultural regions: 1) Class 9, found in the southern Great Plains and eastern Washington, is cropland planted primarily in winter wheat; and 2) Class 17, found in the midwest corn belt, is cropland planted primarily in feed grains, especially corn and soybeans. Both NDVI profiles exhibit steep increases and decreases in greenness corresponding to crop development, senescence, and harvest. In the corn-soybeans region, greenness begins its increase in May as crops emerge, peaks in midAugust as these crops reach their maximum biomass and photosynthetic activity, and decreases in September as senescence and harvest set in. In the winter wheat region, by contrast, greenness increases in March as fall-sown winter wheat emerges in early spring, peaks in late-April, and decreases in early summer as crops are harvested.

Figure 3 presents the profiles for two classes dominated by deciduous forest: 1) Class 92 in the northern Great Lakes States is dominated by maple, birch, and beech forests; and 2) Class 94 in the central Appalachian Mountains and northern Ozarks is dominated by oak and hickory forests. In the former, the onset of greenness occurs in May with the emergence

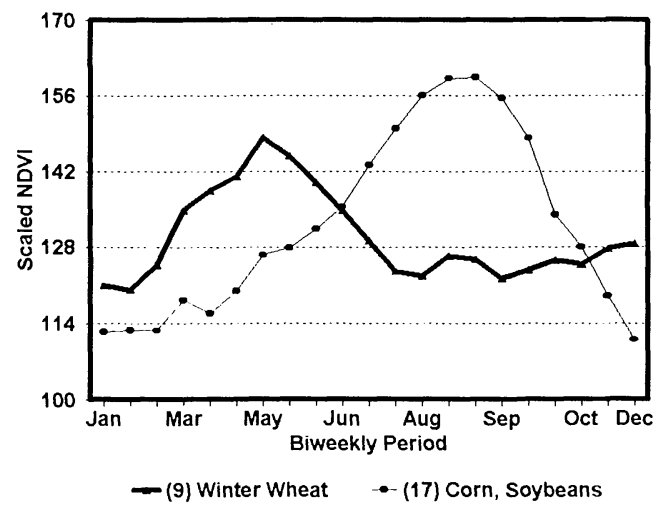

Figure 2. $1990 \mathrm{NDVI}$ characteristics for selected seasonal land-cover regions: winter wheat and cornsoybeans. 


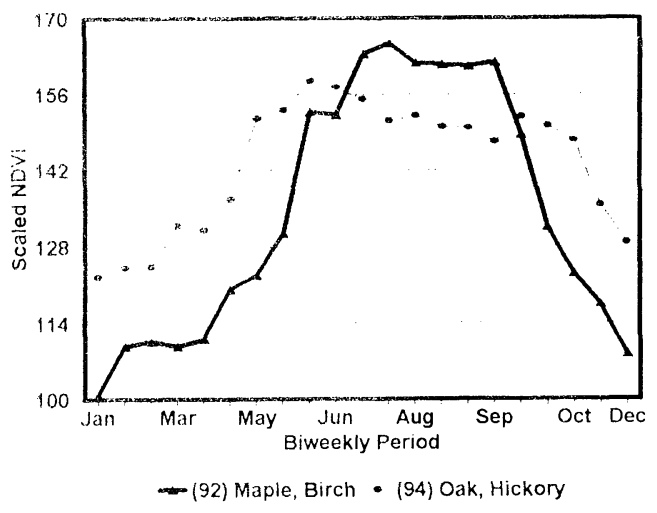

Figure 3. 1990 NDVI characteristics for selected seasonal land-cover regions: maple-birch and oakhickory.

of leaves, is followed by a steep increase in the NDVI from spring to the summer period of maximum photosynthesis, and then by a rapid decline in NDVI levels in September as leaves change color and defoliate. In the latter, the shape of the greenness profile is similar to that of the northern hardwoods region, but the onset of greenness (April) is earlier because of the more southerly latitude. In addition, the longer growing season occasions later defoliation (late-October).

Figure 4 depicts two coniferous forest types: 1) Class 98 is dominated by southern pines, including loblolly, longleaf, shortleaf, and slash pines; and 2) Class 105 is comprised principally of lodgepole and ponderosa pine in Colorado. In the case of the southern pines, the evergreen forest cover results in a relatively high NDVI level throughout the year. The decrease in the NDVI in January and February likely is attributable to low sun angles, the corresponding shadows of mid-winter, and reduction of the forest understory. As for the Colorado pine, the greenness profile describes a distinct seasonality that more nearly resembles the NDVI profiles for deciduous cover types. In this case, the rapid increase in NDVI values in late-April and May probably results from higher sun angles, the gradual melting of the winter snow cover, and the subsequent development of the forest understory.

Figure 5 displays NDVI profiles for two

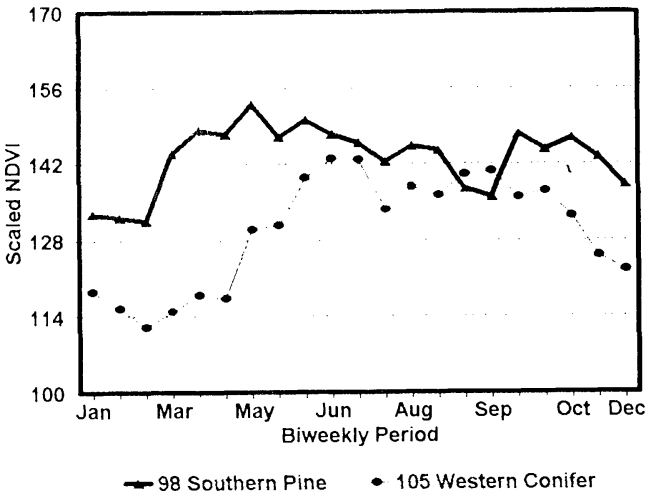

Figure 4. 1990 NDVI characteristics for selected seasonal land-cover regions: southern pine and western conifer.

rangeland regions: 1) Class 74 is composed primarily of shrubs (big sage and rabbitbrush) and cool-season grasses (wheat grass and fescue) distributed throughout Washington, Oregon, and Idaho; and 2) Class 77 is a mixture of shrubs (creosote and sand sage) and warmseason grasses (grama) found principally in the southwestern U.S. Note that overall NDVI levels are lower here than in forested and agricultural regions, a reflection of the lower amounts of standing primary production in these

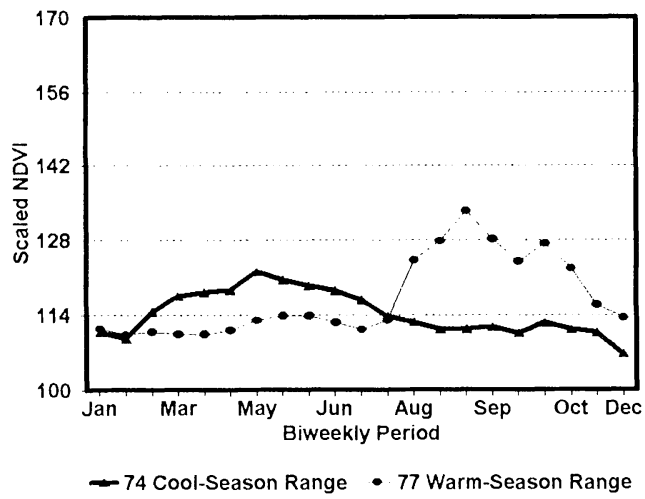

Figure 5. 1990 NDVI characteristics for selected seasonal land-cover regions: cool-season rangeland and warm-season rangeland. 


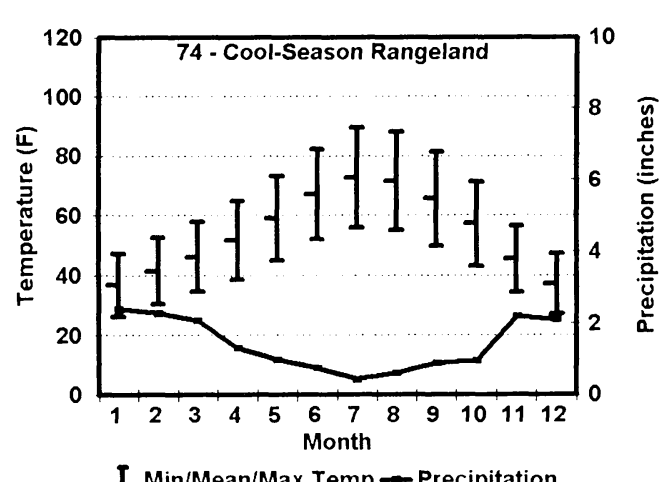

I Min/Mean/Max Temp - Precipitation

Figure 6. Monthly temperature and precipitation (30-year averages) in areas within rangeland class 74 . This graph illustrates the influence of climate variables on NDVI signals (see Figure 5 to compare the NDVI profile for class 74 cool-season grasses).

semiarid environments. The profiles for these classes also illustrate the response of vegetation to rainfall patterns in semiarid climates. The profile for Class 74 (in the Northwest) exhibits a spring green period that is related to late winter and early spring rains, while the profile for class 77 (in the Southwest) shows a later increase and peak greenness triggered by summer rainfall (Figures 6 and 7).

Our maps of the land-cover characteristics in the U.S. presented here are for 1990, hence they reflect climatic conditions in that year. As Changnon and Kunkel (1992) have pointed out, 1990 was an anomalous weather year in the midwest where it was both the warmest and wettest year on record. They also note that weather conditions across the country in 1990 were unusual. The year was the seventh warmest and the fourteenth wettest on record since 1895. Above normal precipitation between January and June in the midwest delayed the growing season (planting) by several weeks. Weather conditions also led farmers to shift more than 18 million acres from corn to soybeans. In addition, the cool and wet spring favored pest development, and higher-thannormal winds in spring and summer minimized opportunities to spray crops. The effects of these combined phenomena are reflected in the database and in the AVHRR-derived maps.

Because AVHRR data are continuously col-

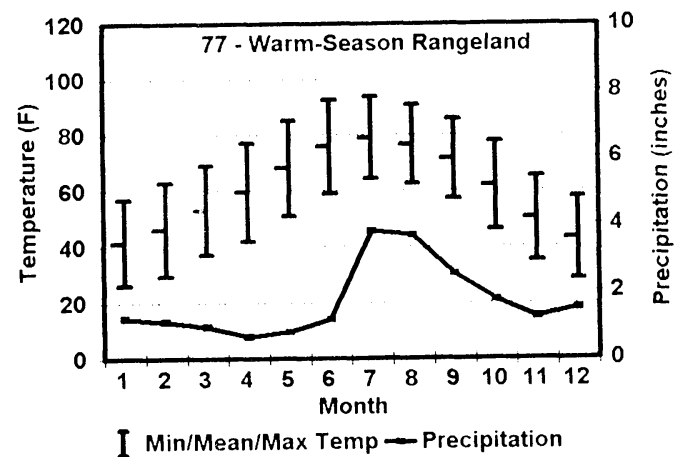

Figure 7. Monthly temperature and precipitation (30-year averages) in areas within rangeland class 77. This graph illustrates the influence of climate variables on NDVI signals (see Figure 5 to compare the NDVI profile for class 77 warm-season grasses).

lected and archived, it is possible to examine seasonal land-cover-climate relationships for years since 1990. The USGS EROS Data Center now provides AVHRR biweekly greenness data as a standard CD-ROM product (Eidenshink and Hutchinson 1993). Explorations of the seasonal manifestations of greenness-weather relationships for the U.S. land-cover regions over the period 1990-1993 are currently underway (Reed et al. 1994a).

\section{Evaluation of the Database}

Methods for determining the accuracy of products generated via remote sensing are well-developed for conventional image-analysis projects covering relatively small areas (Congalton 1991), but techniques for validation of continental-scale or global-scale maps and databases are still at an earlier stage of development (Goodchild 1988). The usual procedure involves assessing the results of an analysis of remotely-sensed data against "ground truth." In the case of the U.S. database, however, almost $80001-\mathrm{km}$ contemporaneous samples on the ground would be required to conduct a conventional accuracy assessment (Congalton 1991). Moreover, it is far from clear what standard of reference should be used to compare the U.S. land-cover regions (Merchant et al. 1994). The classification methods 
and the data used, the number and types of categories mapped, and the spatial resolution of the U.S. database project differ considerably from those employed in conventional landcover mapping efforts. Consequently, no rigorous accuracy assessment of the U.S. database has as yet been completed.

Nevertheless, a number of preliminary studies indicate that the database offers a reasonable depiction of U.S land cover. D. P. Turner et al. (1993), evaluating an early version of the database, compared forested areas in the 1990 U.S. database with the 1987 forest inventory data of the U.S. Forest Service (USFS). Their state-, regional-, and national-level areal assessments in states having large contiguous tracts of forest cover report close agreement between the USFS data and the AVHRR-derived estimates of forest. At the national level, the USFS and AVHRR estimates of forested land differed by only about 4 percent. Similar estimates for county forest cover in the northeastern portion of the U.S. indicate that the two sources compare very favorably (Lathrop and Bogner 1994), subject however to the caveat that validation is difficult because of the differences between the classification schemes used by the USFS and the AVHRR database.

Similar agreement has been found by Merchant et al. (1994) who compared portions of the U.S. database to several independently developed state land-cover maps (Tables 3 and 4). When AVHRR-derived data for Nebraska were compared to USGS land-use and landcover (USGS/LULC) maps derived from interpretation of high-altitude aerial photography and to the U.S. Department of Agriculture (USDA) areal land-use data, they found the cropland/grassland estimates within 3 percent (USGS/LULC) and 8.3 percent (USDA), cropland only estimates within 1 percent (USDA only), rangeland only estimates within 8 percent (USGS/LULC) and 10 percent (USDA), and forest estimates within 0.7 percent (USGS/LULC) and 1.0 percent (USDA). The AVHRR-derived land-cover data and USDA land-use data were also compared to a SPOT land-cover classification for South Carolina (Table 4) and, in this case, agreement was within 2 percent (SPOT) and 0.4 percent (USDA) for agriculture and grassland, and within 2 percent (SPOT) and 0.6 percent (USDA) for forests. Differences between the estimates are related to the coarse resolution of the AVHRR, time
Table 3. Land-Cover Estimates for Nebraska, Based on Data for the AVHRR Land Cover, USDA Land Use, and USGS Land-Use/Land Cover (LU/LC).

\begin{tabular}{lccc}
\hline & $\begin{array}{c}\text { AVHRR } \\
\text { (percent) }\end{array}$ & $\begin{array}{c}\text { USGS/LULC } \\
\text { (percent) }\end{array}$ & $\begin{array}{c}\text { USDA } \\
\text { (percent) }\end{array}$ \\
\hline $\begin{array}{l}\text { Cropland or } \\
\text { grassland }\end{array}$ & 99.3 & 96.3 & 91.0 \\
Cropland & 40.0 & Not available & 41.0 \\
Rangeland & 32.0 & 40.0 & 42.0 \\
Forest & 0.5 & 1.2 & 1.5 \\
\hline
\end{tabular}

differences between the datasets, and so on. Forest cover in Nebraska, for instance, is probably underestimated by the AVHRR because this type of land cover tends to occur in small parcels relative to the $1-\mathrm{km}$ sensor resolution.

At the national level, Merchant et al. (1994) compared the AVHRR land-cover database to USDA/National Agricultural Statistical Service (NASS) county-level data on cropped area. That comparison indicated that the estimates of absolute cropped area in the two datasets were significantly and positively correlated $\left(r=.825, r^{2}=.680\right)$. A similar association was observed for the proportion of each county in cropland. The authors also concluded that preliminary efforts to validate the AVHRR-derived U.S. land-cover characteristics database, though generally positive, have not been conclusive because: 1) they have been based on areal rather than site-specific comparisons; and 2 ) the accuracies of the "benchmark" data are not well documented.

The need for improved methods for the quantitative validation of large-area, coarse-

Table 4. Land-Cover Estimates for South Carolina, Based on Data for the AVHRR Land Cover, USDA Land Use, and SPOT Satellite Image Classification.

\begin{tabular}{lccc}
\hline & $\begin{array}{c}\text { AVHRR } \\
\text { (percent) }\end{array}$ & $\begin{array}{c}\text { SPOT } \\
\text { (percent) }\end{array}$ & $\begin{array}{c}\text { USDA } \\
\text { (percent) }\end{array}$ \\
\hline $\begin{array}{l}\text { Agriculture or } \\
\text { grassland }\end{array}$ & 19 & 21 & 18.6 \\
\begin{tabular}{l} 
Forest \\
\hline
\end{tabular} & 64 & 66 & 63.4 \\
\hline
\end{tabular}


resolution, land-cover databases is obvious. Until such time as these methods are available, we believe that validation procedures must rely to a great extent on subjective evaluation of the data and on accumulation of evidence supporting or refuting the validity of a specific product (Merchant et al. 1994). The cumulative evidence currently available suggests that the AVHRR-derived land-cover characteristics database is a valid representation of land cover in the United States. In addition to the comparative efforts summarized above, this evidence includes extensive preliminary confirmation of database utility by modelers and other database users (Steyeart et al. 1994) and affirmation of the internal logical consistency in the database (Merchant et al. 1994). And more evidence is on the way in the form of a more objective assessment of the accuracy of the U.S. land-cover database by the USDA/Forest Service and EROS Data Center. Initiated in 1993, this project surveyed approximately 3500 field sites throughout the coterminous U.S.; results of this study are currently being analyzed.

\section{Conclusions}

The U.S. land-cover project has demonstrated that multidate-coarse-resolution meteorological satellite data can provide new information about the regional expression of land cover and its seasonal characteristics. This information is useful for many global-change research initiatives and for a broad array of other environmental applications. Seasonal landcover data derived from analysis of AVHRR imagery readily complement land-cover data obtained through more traditional means (e.g., Landsat, SPOT). The maps presented here illustrate some of the products that may be generated from the land-cover characteristics database, and they point to the flexibility of a database which can be tailored to meet specific requirements.

This paper in particular presents a new classification of U.S. land cover based on AVHRR data. One hundred fifty-nine seasonal landcover regions are described and mapped according to their vegetative composition, phenology (onset, peak, and length of green period), relative productivity, and other landscape parameters. These seasonal land-cover regions and their unique sets of landscape conditions lend themselves to many types of large-area analyses, not least as a spatial framework for measurement, interpolation, and extrapolation of land parameters.

The strength of the land-cover database described here resides in its unification of landcover data with a suite of landscape descriptors; the regional classes thus are not simply descriptive labels. Moreover, users are provided with data that are consistent in quality; useful for a variety of scientific applications; and descriptive of the temporal dynamics of landscapes. The database overcomes the problem of customized applications which use similar, but not identical, categorizations that are specific to organization, discipline, or application. Our land-cover characteristics database has the advantage of adaptability to a range of problems.

This research has suggested the possibility of constructing a global land-cover characteristics database using $1-\mathrm{km}$ meteorological satellite imagery and ancillary data. Such an endeavor is now underway, and completion is anticipated by late 1997. Coordinated through the International Geosphere-Biosphere Programme (IGBP 1994), the global database is being developed on a continent-by-continent basis using methods developed in the U.S. project. North and South America will be completed by late 1995. Concurrent research is being directed toward improving our analytic techniques, efficiency, and the quality of the results. More specifically, we are investigating means for validating large-area land-cover databases, the interannual variability of landcover and associated issues, methods for objectively defining seasonal parameters, and visualization techniques for data analysis.

\section{Note}

1. The land-cover characteristics database for the coterminous U.S. (including all data outlined in Table 2) is available on CD-ROM. These data can be imported into most raster-based image processing and GIS software packages. U.S. AVHRR NDVI composite data from 1989 to the present and a companion containing additional spatial datasets for the coterminous U.S. are also available on two CD-ROMs. To obtain additional information, contact Customer Services, USGS/EROS Data Center, Sioux Falls, SD 57198; Telephone: 605-594-6151. 


\section{Acknowledgments}

The U.S. Geological Survey has provided all funding for production and printing of the Map Supplement. Hughes STX Corporation performed their work under U.S. Geological Survey contract 143492-C-40004. Research support for participating University of Nebraska-Lincoln (UNL) staff was provided by the U.S. Environmental Protection Agency (Grant X007526-01), the U.S. Geological Survey, and the UNL Conservation and Survey Division.

\section{References}

Anderson, J. R., Hardy, E. E., Roach J. T., and Witmer, R. E. 1976. A Land Use and Land Cover Classification System for Use with Remote Sensor Data. U.S. Geological Survey Professional Paper 964. Reston, Virginia: U.S. Geological Survey.

Bailey, R. G. 1980. Description of the Ecoregions of the United States. USDA/Forest Service Miscellaneous Publication 1391. Washington, D.C.: U.S. Department of Agriculture, Forest Service.

- 1983. Delineation of Ecosystem Regions. Environmental Management 7:365-373.

Baker, W. L. 1989. A Review of Models of Landscape Change. Landscape Ecology 2:111-133.

Box, E. O., Holben, B. N., and Kalb, V. 1989. Accuracy of the AVHRR Vegetation Index as a Predictor of Biomass, Primary Productivity, and Net $\mathrm{CO}_{2}$ Flux. Vegetatio 30:71-89.

Brown, J. F., Loveland, T. R., Merchant, J. W., Reed, B. C., and Ohlen, D. O. 1993. Using Multisource Data in Global Land Cover Characterization: Concepts, Requirements and Methods. Photogrammetric Engineering and Remote Sensing 59:977-987.

Burke, I. C., Kittel, T. G., Lauenroth, W. K., Snook, P., Yonker, C. M., and Parton, W. J. 1991. Regional Analysis of the Central Great Plains: Sensitivity to Climate Variability. Bioscience 41:685-689.

Campbell, J. B. 1983. Mapping the Land: Aerial Imagery for Land Use Information. Washington, D.C.: Association of American Geographers.

Changnon, S. A., and Kunkel, K. E. 1992. Assessing Impacts of a Climatologically Unique Year (1990) in the Midwest. Physical Geography 13:180190.

Clarke, S. E., White, D., and Schaedel, A. L. 1991. Oregon, USA, Ecological Regions and Subregions for Water Quality Management. Environmental Management 15:847-856.

Congalton, R. G. 1991. A Review of Assessing the Accuracy of Classifications of Remotely Sensed Data. Remote Sensing of Environment 37:35-46.

Danko, D. M. 1992. The Digital Chart of the World. Geolnfo Systems 2:29-36.

Dent, B. D. 1993. Cartography: Thematic Map Design. Dubuque, lowa: W. C. Brown Publishers.
Dickinson, R. E., Henderson-Sellers, A., Kennedy, P. J., and Wilson, M. F. 1986. Biosphere-Atmosphere Transfer Scheme (BATS) for the NCAR Community Climate Model. NCAR Technical Note, NCAR/TN-275+STR. Boulder, Colorado: National Center for Atmospheric Research.

Egbert, S. L., and Slocum, T. A. 1992. EXPLOREMAP: An Exploration System for Choropleth Maps. Annals of the Association of American Geographers 82:275-288.

Ehrlich, D., Estes, J. E., and Singh, A. 1994. Applications of NOAA-AVHRR $1 \mathrm{~km}$ Data for Environmental Monitoring. International Journal of Remote Sensing 15:145-161.

Eidenshink, J. C. 1992. The 1990 Conterminous U.S. AVHRR Data Set. Photogrammetric Engineering and Remote Sensing 58:809-813.

Eidenshink, J. C., and Hutchinson, J. A. 1993. AVHRR Data Set for the Conterminous United States. Research and Exploration, Water Issue, ed. A. de Souza. 9:86-97.

Gallo, K. P., and Brown, J. F. 1990. Satellite-Derived Indices for Monitoring Global Phytoclimatology. In Proceedings of the International Geoscience and Remote Sensing Symposium, pp. 261-264, Piscataway, New Jersey. Institute of Electrical and Electronics Engineers.

Gardiner, V., and Gregory, K. J. 1977. Progress in Portraying the Physical Landscape. Progress in Physical Geography 1:1-22.

Gervin, J. C., Kerber, A. G., Witt, R. G., Lu, Y. C., and Sekhon, R. 1985. Comparison of Level 1 Land Cover Classification Accuracy for MSS and AVHRR Data. International Journal of Remote Sensing 6:47-57.

Goodchild, M. F. 1988. The Issue of Accuracy in Global Databases. In Building Databases for Global Science, ed. H. Mounsey and R. F. Tomlinson, pp. 31-48. London: Taylor and Francis.

Goodchild, M. F., Parks, B. O., and Steyaert, L. T. 1993. Environmental Modeling with Geographic Information Systems. New York: Oxford University Press.

Goward, S. N. 1989. Satellite Bioclimatology. Journal of Climate 2:710-720.

-1990. Experiences and Perspectives in Compiling Long-Term Remote Sensing Data Sets on Landscapes and Biospheric Processes. GeoJournal 20:107-114.

Goward, S. N., and Huemmirch, K. F. 1992. Vegetation Canopy PAR Absorptance and the Normalized Difference Vegetation Index: An Assessment using the SAIL Model. Remote Sensing of Environment 39:119-140.

Goward, S. N., Tucker, C. J., and Dye, D. G. 1985. North American Vegetation Patterns Observed with the NOAA-7 Advanced Very High Resolution Radiometer. Vegetatio 64:3-14.

Grigg, D. 1965. The Logic of Regional Systems. An- 
nals of the Association of American Geographers 55:465-491.

- 1967. Regions, Models and Classes. In Integrated Models in Geography: Parts I and IV of Models in Geography, ed. R. J. Chorley and P. Haggett, pp. 461-509. London: Methuen.

Haggett, P., Cliff, A., and Frey, A. 1977. Locational Analysis in Human Geography. London: Edward Arnold.

Hart, J. F. 1982. The Highest Form of the Geographers Art. Annals of the Association of American Geographers 72:1-29.

Henderson-Sellers, A., and McGuffie, K. 1987. A Climate Modelling Primer. New York: John Wiley.

Henderson-Sellers, A., and Pitman, A. J. 1992. LandSurface Schemes for Future Climate Models: Specification, Aggregation and Heterogeneity. Journal of Geophysical Research 97:2687-2696.

International Geosphere-Biosphere Programme. 1994. IGBP Global Modeling and Data Activities 1994-1998. IGBP Report No. 30. Stockholm, Sweden: The International Geosphere-Biosphere Programme.

Jennings, M. D. 1993. Natural Terrestrial Cover Classification: Assumptions and Definitions. Gap Analysis Technical Bulletin 2. Moscow, Idaho: U.S. Fish and Wildlife Service.

Küchler, A. W. 1964. Potential Natural Vegetation of the Conterminous United States. Special Publication 36. New York: American Geographical Society.

Lathrop, R. G., Jr., and Bognar, J. A. 1994. Development and Validation of AVHRR-Derived Regional Forest Cover Data for the North-Eastern U.S. International Journal of Remote Sensing 15:26952702.

Lloyd, D. 1991. A Phenological Classification of Terrestrial Vegetation Using Shortwave Vegetation Index Imagery. International Journal of Remote Sensing 11:2269-2279.

Loveland, T. R., Merchant, J. W., Ohlen, D. O., and Brown, J. F. 1991. Development of a LandCover Characteristics Database for the Conterminous U.S. Photogrammetric Engineering and Remote Sensing 57:1453-1463.

Ludeke, M., Janecek, A., and Kohlmaier, G. H. 1991. Modelling the Seasonal $\mathrm{CO}^{2}$ Uptake by Land Vegetation using the Global Vegetation Index. Tellus 43B:188-196.

Mather, J. R., and Sdasyuk, G. V., eds. 1991. Global Change: Geographical Approaches. Tucson: University of Arizona Press.

Matthews, E. 1983. Global Vegetation and Land Use: New High Resolution Data Bases for Limited Studies. Journal of Climatology and Applied Meteorology 22:474-487.

Merchant, J. W., Yang, L., and Yang, W. 1994. Validation of Continental-Scale Land Cover Data Bases Developed from AVHRR Data. In Proceedings of the Pecora 12 Symposium, pp. 63-72.
Bethesda, Maryland: American Society for Photogrammetry and Remote Sensing.

National Oceanic and Atmospheric Administration. 1979. Climate Atlas of the United States. Asheville, North Carolina: Environmental Data Services.

Olson, J. S., and Watts, J. A. 1982. Major World Ecosystem Complex Map. Oak Ridge, Tennessee: Oak Ridge National Laboratory.

Omernik, J. M. 1987. Ecoregions of the Conterminous United States. Annals of the Association of American Geographers 77:118-125.

Omernik, J. M., and Gallant, A. L. 1990. Defining Regions for Evaluating Environmental Resources. In Proceedings of the International Conference on Global Natural Resource Monitoring and Assessments: Preparing for the 21st Century, Vol. 2, pp. 936-947. Bethesda, Maryland: American Society for Photogrammetry and Remote Sensing.

Palko, S. 1990. NOAA Satellite Imagery and the National Atlas GIS. Proceedings, Second National GIS Conference, pp. 79-83. Ottawa: Canadian Institute of Surveying and Mapping.

Parton, W. J., Schimel, D. S., Cole, C. V., and Ojima, D. S. 1987. Analysis of Factors Controlling Soil Organic Levels in Great Plains Grasslands. Soil Science Society of America 51:1173-1179.

Peer, R. L. 1990. An Overview of Climate Information Needs for Ecological Effects Models. Research Triangle Park, North Carolina: U.S. Environmental Protection Agency.

Peplies, R. W., and Honea, R. B. 1992. Some Classic Regional Models in Relation to Global Change Studies. Paper presented at the 88th Annual Meeting, Association of American Geographers.

Reed, B. C., Brown, J. F., VanderZee, D., Loveland, T. R., Merchant, J. W., and Ohlen, D. O. 1994a. Measuring Phenological Variability from Satellite Imagery. Journal of Vegetation Science 5:703714.

Reed, B. C., Loveland, T. R., Steyaert, L. T., Brown, J. F., Merchant, J. W., and Ohlen, D. O. 1994b. Designing Global Land Cover Databases to Maximize Utility: The U.S. Prototype. In Environmental Information Management and Analysis: Ecosystem to Global Scales, ed. W. K. Michener, J. W. Brunt and S. G. Stafford, pp. 299-314. London: Taylor and Francis.

Running, S. W. 1990. Estimating Terrestrial Primary Productivity by Combining Remote Sensing and Ecosystem Simulation. In Remote Sensing of Biosphere Functioning, ed. R. J. Hobbs and H. A. Mooney, pp. 65-86. New York: Springer-Verlag. Sellers, P. J., Mintz, Y., Sud, Y. C., and Dalcher, A. 1986. A Simple Biosphere Model (SiB) for Use within General Circulation Models. Journal of Atmospheric Science 43:505-531.

Sklar, F. H., and Costanza, R. 1990. The Development of Dynamic Spatial Models for Landscape 
Ecology: A Review and Prognosis. In Quantitative Methods in Landscape Ecology, ed. M. G. Turner and R. H. Gardner, pp. 239-288. New York: Springer-Verlag.

Spanner, M. A., Pierce, L. L., Running, S. W., and Peterson, D. L. 1990. The Seasonality of AVHRR Data of Temperate Coniferous Forests: Relationship with Leaf Area Index. Remote Sensing of Environment 33:97-112.

Spence, N. A., and Taylor, P. J. 1970. Quantitative Methods in Regional Taxonomy. Progress in Geography 2:1-64.

Steyaert, L., Loveland, T. R., Brown, J. F., and Reed, B. C. 1994. Integration of Environmental Simulation Models with Satellite Remote Sensing and Geographic Information Systems Technologies: Case Studies. In Proceedings of the Pecora 12 Symposium, pp. 407-417. Bethesda, Maryland: American Society for Photogrammetry and Remote Sensing.

Stone, T. A, Schlesinger, P., Houghton, R. A., and Woodwell, G. M. 1994. A Map of Vegetation of South America Based on Satellite Imagery. Photogrammetric Engineering and Remote Sensing 60:541-552.

Tobler, W. R. 1973. Choropleth Maps without Class Intervals? Geographical Analysis 5:262-265.

Townshend, J. R. G., ed. 1992. Improved Global Data for Land Applications. IGBP Report No. 20. Stockholm, Sweden: The International Geosphere-Biosphere Programme.

Townshend, J. R. G., Justice, C. O., and Kalb, V. 1987. Characterization and Classification of South American Land Cover Types. International Journal of Remote Sensing 8:1189-1207.

Townshend, J. R. G., Justice, C. O., Li, W., Gurney, C., and McManus, J. 1991. Global Land Cover Classification by Remote Sensing: Present Capabilities and Future Possibilities. Remote Sensing of Environment 8:243-256.

Tucker, C. J., Gatlin, J. A., and Schneider, S. R. 1984. Monitoring Vegetation in the Nile Delta with NOAA-6 and NOAA-7 AVHRR Imagery. Photogrammetric Engineering and Remote Sensing 50:53-61.

Tucker, C. J., Townshend, J. R. G., and Goff, T. E. 1985. African Land-Cover Classification using Satellite Data. Science 227:369-375.
Tucker, C. J., Vanpraet, C., Boerwinkel, E., and Gaston, A. 1983. Satellite Remote Sensing of Total Dry Matter Production in the Senegalese Sahel. Remote Sensing of Environment 13:461-474.

Turner, B. L., Moss, R. H., and Skole, D. L., eds. 1993. Relating Land Use and Global Land-Cover Change: A Proposal for an IGBP-HDP Core Project. IGBP Report No. 24. Stockholm, Sweden: The International Geosphere-Biosphere Programme.

Turner, D. P., Koerper, G., Gucinski, H., Peterson, C., and Dixon, R. K. 1993. Monitoring Global Change: Comparison of Forest Cover Estimates using Remote Sensing and Inventory Approaches. Environmental Monitoring and Assessment 26:295-305.

UNESCO. 1973. International Classification and Mapping of Vegetation. Paris, France: UNESCO.

U.S. Department of Agriculture. Soil Conservation Service. 1981. Land Resource Regions and Major Land Resource Regions of the United States. Agricultural Handbook 296. Washington, D.C.: U.S. Government Printing Office.

U.S. Geological Survey. 1970. Major Land Uses (map). In The National Atlas of the United States of America. Reston, Virginia: U.S. Geological Survey.

-1986. Land Use and Land Cover Data from 1:250,000- and 1:100,000-Scale Maps. U.S. Geological Survey Data Users Guide Number 4. Reston, Virginia: U.S. Geological Survey.

Woodwell, G. M., Hobbie, J. E., Houghton, R. A., Melillo, J. M., Moore, B., Park, A. B., Peterson, B. J., and Shaver, G. R. 1984. Measurement of Changes in the Vegetation of the Earth by Satellite Imagery. In The Role of Terrestrial Vegetation in the Global Carbon Cycle: Measurement by Remote Sensing, ed. G. M. Woodwell, pp. 221240. New York: John Wiley.

Xue, Y., Sellers, P. J., Kinter, J. L., and Shukla, J. 1991. A Simplified Biosphere Model for Global Climate Studies. Journal of Climate 4:345-364.

Zhu, Z., and Evans, D. L. 1994. U.S. Forest Types and Predicted Forest Cover from AVHRR Data. Photogrammetric Engineering and Remote Sensing 60:525-532.

Submitted 12/93, Revised 7/94, Accepted 10/94.

Loveland, Thomas R., Merchant, James W., Brown, Jesslyn F., Ohlen, Donald O., Reed, Bradley C., Olson, Paul, and Hutchinson, John. 1995. Seasonal Land-Cover Regions of the United States. Annals of the Association of American Geographers 85(2):339-355. Abstract.

Global-change investigations have been hindered by deficiencies in the availability and quality of land-cover data. The U.S. Geological Survey and the University of Nebraska-Lincoln have collaborated on the development of a new approach to land-cover characterization that attempts 
to address requirements of the global-change research community and others interested in regional patterns of land cover. An experimental 1-kilometer-resolution database of land-cover characteristics for the coterminous U.S. has been prepared to test and evaluate the approach. Using multidate Advanced Very High Resolution Radiometer (AVHRR) satellite data complemented by elevation, climate, ecoregions, and other digital spatial datasets, the authors define 159 seasonal land-cover regions. The regionalization is based on a taxonomy of areas with respect to data on land cover, seasonality or phenology, and relative levels of primary production. The resulting database consists of descriptions of the vegetation, land cover, and seasonal, spectral, and site characteristics for each region. These data are used in the construction of an illustrative 1:7,500,000-scale map of the seasonal land-cover regions as well as of smaller-scale maps portraying general land cover and seasonality. The seasonal land-cover characteristics database can also be tailored to provide a broad range of other landscape parameters useful in national and global-scale environmental modeling and assessment. Key Words: global change, land cover, phenology, remote sensing.

Correspondence: U.S. Geological Survey, EROS Data Center, Sioux Falls, South Dakota, 57198 (Loveland); Center for Advanced Land Management Information Technologies, Conservation and Survey Division, Institute of Agriculture and Natural Resources, University of Nebraska, Lincoln, Nebraska, 68588 (Merchant); Hughes STX Corporation, EROS Data Center, Sioux Falls, South Dakota, 57198 (Brown, Ohlen, Reed, Olson, and Hutchinson). 